\title{
The importance of the renewable energy sector in the opinion of rural and urban youth
}

ABSTRACT: The growing interest in green energy observed in recent years has become the basis for pilot studies on its electricity production role in Poland. The diagnostic survey method allowed us to learn about young people's opinions on renewable energy sources in the context of four identified research areas (the need for RES, planning its installation, costs, environmental impact). The authors proposed a method based on fuzzy logic (fuzzy relations and optimistic fuzzy aggregation norms) to develop and interpret the survey results to understand the selected community's knowledge about the importance of RES (or not) in the national energy system. The survey shows that although there is no significant difference between respondents in all research areas, rural women are more interested in using green technologies. They have a high self-awareness of their beneficial effects on the environment. Rural respondents, compared to those from the cities, are willing (despite the high cost of equipment) to invest their capital to purchase green energy carriers, which is dictated by their lower knowledge about the forms of external support. Depending on the residence place, re-

$\checkmark$ Corresponding Author: Aleksandra Mreła; e-mail: a.mrela@ukw.edu.pl

${ }^{1}$ Faculty of Civil and Environmental Engineering and Architecture, University of Science and Technology in Bydgoszcz, Poland; ORCID iD: 0000-0003-1285-0101; e-mail: jolanta.cichowska@utp.edu.pl

${ }^{2}$ Institute of Informatics, Kazimierz Wielki University in Bydgoszcz, Poland; ORCID iD: 0000-0002-2059-864X; e-mail: a.mrela@ukw.edu.pl

3 Department of Informatics, Faculty of Physics, Astronomy and Informatics, Nicolaus Copernicus University in Toruń, Poland; ORCID iD: 0000-0002-6531-2203; e-mail: osokolov@fizyka.umk.pl

2021. The Author(s). This is an open-access article distributed under the terms of the Creative Commons Attribution-ShareAlike International License (CC BY-SA 4.0, http://creativecommons.org/licenses/by-sa/4.0/), which permits use, distribution, and reproduction in any medium, provided that the Article is properly cited. 
spondents selected various government aid programs for renewable energy. People from the city decided mainly on those that would improve the air's comfort and quality in their place of residence. On the other hand, the rural areas' inhabitants focused their attention on the aid possibilities, which would reduce the energy costs of the farms they run in the future. All the respondents agree that investments in clean energy (coming from natural sources) will translate into broadly understood environmental protection, bringing mutual benefits for everyone.

KEYWORDS: renewable energy sources, clean energy, university students, fuzzy logic, fuzzy aggregation norms

\section{Introduction}

The progressive degradation of the environment and depletion of natural resources have implemented ecological energy sources more critical in the world. The interest in renewable energy sources (RES) has become a necessity due to the observed rate of increase in energy demand, which is related to the continuous improvement of society's quality of life. These changes forced the introduction of integrated global actions towards the opening of a sustainable energy sector. According to (Manowska 2019), an unusually high growth rate of renewable power in the world was noticed in 2017. This tendency was also maintained in the following the years 2018-2020. Technologies such as hydropower, bioenergy, geothermal energy, and heat have been recognized as the primary and cost-competitive energy source. In turn, photovoltaics and wind energy, in particular, compete with new fossil fuel capacities (Manowska 2019). It is estimated that they will have the largest share in the energy sector transformation and will dominate RES. It will increase the production of green energy by $60 \%$ in 30 years (from $25 \%$ in 2017 to $85 \%$ in 2050). (Fells 1996; 2000) also emphasized the validity of such measures in his papers, stressing that these technologies have to increase their electricity production share. Nevertheless, the development of renewable energy in the world depends not only on the possibility of using this potential (including the geographical location of the installation) and on the policy of a given country supporting the development of such energy carriers (Sowa 2018). In its energy policy, Poland declares as part of the EU-wide goal to reach the amount of $21-23 \%$ of RES in gross final energy consumption by 2030 (total consumption electricity, heating, and cooling, and transport purposes). However, these optimistic plans may be difficult to achieve if Poland does not take immediate steps to create incentives to increase renewable energy use in all sectors of the economy. The scenario, which (Janeiro and Resch 2017) assumed that the 15\% RES target achievement before 2020 would not be met, has been confirmed. It was the EU, mainly due to Sweden, Finland, and Latvia's activities, that achieved significant success in this respect, almost achieving the $20 \%$ target (19.7\%) for 2020 (Perzyński 2020). Irrespective of the national, EU, and global assumptions, the creation of mechanisms and incentives to implement environmentally safe technologies in the coming years is necessary. 
According to (Pawlak 2019), significant changes have occurred in recent years related to the possibilities of building these sources in the household, which are described in detail by (Santos et al. 2017). Therefore, the paper's primary purpose is to check how young urban and rural residents perceive the importance and development of ecological energy carriers on the domestic market.

The issues raised are of great importance for environmental protection because, as (Owusu and Asumadu-Sarkodie 2016) emphasized, reducing the carbon footprint through the changes in lifestyle and behavior patterns can contribute a great deal to the moderation of climate change, which is a severe global threat (Ash 2001). Therefore, securing energy supplies from non-fossil sources can reduce greenhouse gases (Houghton 2001). Since the level of knowledge of the society is varied in terms of the understanding of issues related to renewable energy sources (especially in the context of economic or environmental benefits resulting from their use), the analyses will be based on four research groups (urban and rural men and women). Due to different residence places, respondents might be inspired by varied stimuli to understanding these issues. According to (Babbie 2001), apart from observing and interpreting the obtained results, the fundamental goal is to specify the unit of analysis and determine if there is a relationship between the studied variables. The investigations were carried out, and the knowledge obtained through testing the young people's opinions about ecological energy carriers can play an essential role in defining the young generation's needs and expectations in terms of products and solutions introduced to the market. Renewable energy is a future hope for energy expansion for society worldwide due to its abundance in nature, environmentally clean, and affordable cost once its installation was made (Geleta and Manshahia 2017; Szczerbowski and Ceran 2017).

\section{Materials and methods}

The research was a pilot study, and to conduct this survey, a research institution located in the place of residence of the publication authors was selected. The main objective of the study was, in particular, to determine whether:

$A_{1}$ - there is a need to invest in green energy in the country,

$A_{2}$ - young people plan to invest in ecological energy carriers in the future,

$A_{3}$ - young people are orientated as to the amount of financial outlays incurred for this purpose and existing state support forms,

$A_{4}$ - renewable energy sources have a significant impact on environmental protection.

Surveys were conducted employing a diagnostic questionnaire in 2019 on 236 people studying at one of the Polish universities. Out of the total number of people surveyed, $64 \%$ (i.e., 151 ) were city dwellers ( $58.9 \%$ men and $41.1 \%$ women), and $36 \%$ were rural residents $(54.1 \%$ women and $45.9 \%$ men). The respondents mainly represented two age groups: $20-24$ (67.4\%) 
and 18-19 (24.6\%). The selection of this segment of respondents was purposeful because university students have similar characteristics, identifying themselves (despite differences) with a specific system of values or views. This was dictated by the fact that the authors plan, in the future, to expand and conduct research among students of several universities with different educational profiles to know and compare their points of view in sustainable energy sources (taking their gender and place of residence into account). As scientists usually conduct this type of research in small groups (50-100 people), we considered that the initially adopted sample size (250 people) was sufficient. Nevertheless, we did not include 14 questionnaires in the analyzes due to their minimal filling.

The questionnaire consisted of 27 questions, and we only chose 8 of them (the other ones do not contribute much to our research areas $A_{1}, A_{2}, A_{3}, A_{4}$ ):

$Q_{1}$ - What kinds of renewable energy sources do you know?

$Q_{2}$ - Do you know what devices/technologies are used for this purpose?

$Q_{3}$ - Do you think that we should invest in renewable energy in Poland?

$Q_{4}$ - Do you/your close family plan to invest in renewable energy in the next years?

$Q_{5}$ - Do you know forms of financial support for installing renewable energy sources?

$Q_{6}$ - Do you think that if you want to invest in renewable energy, you have to spend much money?

$Q_{7}$ - Do you think that state support in the field of renewable energy support is sufficient?

$Q_{8}$ - Do you think that renewable energy sources contribute to environmental protection?

In the case of questions $Q_{1}, Q_{2}$ and $Q_{5}$, respondents can name a different number of answers, so take the following assumption: a maximum of 4 replies from respondents are considered. The remaining questions consisted of a series of statements to which respondents responded by pointing to one of the proposed alternative terms (yes, rather yes, rather not, no, I don't know). The Likert scale (Likert 1932) used here is the result of young people's answers to the question to what extent they agree (or disagree) with a given statement (Sołoma 2002).

The authors propose a fuzzy logic method to analyze the survey results, which agrees with using fuzzy methods and techniques to solve different problems more often (Zadeh 1965; Sidhu et al. 2014; Chandran and Kandaswamy 2016).

The authors propose a fuzzy logic method to analyze the survey results, which they called fuzzy logic application in survey research (FLASR). Let us recall the formal definition. Assume that $X$ is a non-empty space. The set $A \subseteq X$ is called fuzzy if $A=\left\{\left(x, \mu_{A}\right) ; x \in X\right\}$, where $A \subseteq X$ and $\mu_{A}: X \rightarrow[0,1]$ is a membership function, which describes this abovementioned level of truth. Let, for example, $X$ be a space of people and be a set of people who were asked the question, 'Do you think that RES impacts the environment'? If somebody answers the considered question 'I think that renewable energy sources contribute to environmental protection but are very expensive and the equipment used for energy production burden the environment', the membership function $\mu_{A}$ might be equal to $\mu_{A}=0.4$. Of course, this is a subjective estimation. Somebody else might estimate the truth of this statement with a different value.

If we consider the Cartesian product of two spaces, namely $X \times Y$ and if $R \subseteq X \times Y$ is a fuzzy set, we call $R$ a fuzzy relation. 
In the paper, the following spaces are considered:

$\checkmark P=\left\{P_{i}, i=1,2, \ldots, I\right\}-$ the set of respondents (here $I=236$ );

$\downarrow Q=\left\{Q_{j}, j=1,2, \ldots, J\right\}$ - the set of questions administered to people (here $J=8$ );

$\checkmark A=\left\{A_{k}, k=1,2, \ldots, K\right\}$ - the set of research areas (here $K=4$ ).

Based on these spaces, the following fuzzy relations can be defined:

$\checkmark R_{1} \subseteq A \times Q$, where $R_{1}\left(A_{k}, Q_{j}\right)$ denotes the explanation level that question $Q_{j}$ gives to the research area $A_{k}$;

$\downarrow R_{2} \subseteq Q \times P$, where $R_{2}\left(Q_{j}, P_{i}\right)$ means the level of truth which person $P_{i}$ estimates to question $Q_{j}$;

$\downarrow R_{3} \subseteq A \times P$, where $R\left(A_{k}, P_{i}\right)$ denotes the level of understanding of research area $A_{k}$ represented by person $P_{i}$.

Based on fuzzy relations $R_{1}$ and $R_{2}$, we applied the $S$-T-composition of fuzzy relations to get the relation $R_{3}=R_{1} \circ R_{2}$ as follows (comp. Rutkowski 2009).

$$
R_{3}\left(A_{k}, P_{i}\right)=S_{j=1,2, \ldots, J}\left(T\left(R_{1}\left(A_{k}, Q_{j}\right), R_{2}\left(Q_{j}, P_{i}\right)\right)\right)
$$

for each $k$ and $i$. The values of relation $R_{3}$ also belong to interval [0,1]. In the paper, the $T$ - and $S$-norms are defined in the following way:

$$
S(x, y)=x+y-x y \quad \text { and } \quad T(x, y)=x y
$$

When we consider $n$ values $x_{1}, \ldots, x_{n}$, we can write $S$ in the form

$$
S\left(x_{1}, \ldots, x_{n}\right)=1-\left(1-x_{1}\right) \cdot \ldots \cdot\left(1-x_{n}\right)
$$

Table 1 presents the relation $R_{1}$ between the research areas and the questions, in which truth levels were estimated by the authors (experts). For example, question $Q_{1}$ explains research area $A_{1}$ at level 0.5 and question $Q_{4}$ contributes explaining this area on level 0.8 .

TABLE 1. The values of relation $R_{1}$ between research areas and questions

TABELA 1 . Wartości relacji $R_{1}$ między obszarami badawczymi i pytaniami

\begin{tabular}{|c|l|l|l|l|l|l|l|l|}
\hline Questions & $Q_{1}$ & $Q_{2}$ & $Q_{3}$ & $Q_{4}$ & $Q_{5}$ & $Q_{6}$ & $Q_{7}$ & $Q_{8}$ \\
\hline Research areas & 0.5 & 0.5 & 0.4 & 0.8 & 0 & 0.4 & 0.4 & 0.5 \\
\hline$A_{1}$ & 0 & 0.5 & 0.2 & 0.8 & 0.4 & 0.4 & 0.7 & 0.4 \\
\hline$A_{2}$ & 0 & 0 & 0 & 0 & 0.5 & 0.7 & 0.8 & 0.2 \\
\hline$A_{3}$ & 0.7 & 0.5 & 0.5 & 0.8 & 0.7 & 0.2 & 0.7 & 0.8 \\
\hline$A_{4}$ & & & & & & \\
\hline
\end{tabular}

Source: authors' estimations. 
Values of relation $R_{2}$ between people and questions are prepared based on the results of the survey. Table 2 shows part of this relation.

TABLE 2. The values of relation $R_{2}$ between the respondents and questions

TABELA 2. Wartości relacji $R_{2}$ między respondentami a pytaniami

\begin{tabular}{|c|l|l|l|l|l|l|l|l|l|l|}
\hline Questions & $P_{1}$ & $P_{2}$ & $P_{3}$ & $P_{4}$ & $P_{5}$ & $P_{6}$ & $P_{7}$ & $P_{8}$ & $P_{9}$ & $P_{10}$ \\
\hline$Q_{1}$ & 0.5 & 0.75 & 1 & 0.75 & 1 & 0.75 & 0.75 & 0.75 & 0.75 & 0.5 \\
\hline$Q_{2}$ & 0.75 & 0.75 & 1 & 0.5 & 1 & 0.25 & 0.75 & 0.5 & 0.75 & 0.5 \\
\hline$Q_{3}$ & 1 & 1 & 1 & 0.75 & 1 & 1 & 1 & 0.75 & 1 & 0.75 \\
\hline$Q_{4}$ & 0.5 & 0.25 & 1 & 0.25 & 0.25 & 0.25 & 0.25 & 0.25 & 0.25 & 0.25 \\
\hline$Q_{5}$ & 0 & 0.25 & 0.75 & 0.5 & 0 & 0.25 & 0.25 & 0.5 & 0 & 0 \\
\hline$Q_{6}$ & 0.75 & 0.75 & 0.75 & 0.75 & 1 & 0.75 & 0.75 & 0.75 & 1 & 0.75 \\
\hline$Q_{7}$ & 0 & 0.5 & 0.25 & 0 & 0.25 & 0.25 & 0.75 & 0 & 0.5 & 0.5 \\
\hline$Q_{8}$ & 0.75 & 1 & 1 & 0.5 & 1 & 1 & 1 & 0.5 & 1 & 1 \\
\hline
\end{tabular}

Source: estimations based on respondents' answers.

To calculate values of relation $R_{3}$, we use the $S$-T-composition defined by (1) with $S$ and $T$ norms described by (2), (3). Hence, for $k=1, \ldots, 5$ and $i=1,2, \ldots, 236$.

$$
R_{3}\left(A_{k}, P_{i}\right)=1-\left(1-R_{1}\left(A_{k}, Q_{1}\right) \cdot R_{2}\left(Q_{1}, P_{i}\right)\right) \cdot \ldots \cdot\left(1-R_{1}\left(A_{k}, Q_{8}\right) \cdot R_{2}\left(Q_{8}, P_{i}\right)\right)
$$

For example

$$
\begin{aligned}
R_{3}\left(A_{1}, P_{1}\right) & =1-\left(1-R_{1}\left(A_{1}, Q_{1}\right) \cdot R_{2}\left(Q_{1}, P_{1}\right)\right) \cdot \ldots \cdot\left(1-R_{1}\left(A_{k}, Q_{8}\right) \cdot R_{2}\left(Q_{8}, P_{i}\right)\right)= \\
& =1-(1-0.5 \cdot 0.5) \cdot(1-0.5 \cdot 0.75) \cdot \ldots \cdot(1-0.5 \cdot 0.75)=0.863
\end{aligned}
$$

so the knowledge of respondent denoted by about research area is very high. Table 3 presents the part of relation:

TABLE 3. The values of the part of relation $R_{3}$ between research areas and respondents

TABELA 3. Wartości części relacji $R_{3}$ pomiędzy obszarami badawczymi a respondentami

\begin{tabular}{|c|c|c|c|c|c|c|c|c|c|c|}
\hline Respondents & $P_{1}$ & $P_{2}$ & $P_{3}$ & $P_{4}$ & $P_{5}$ & $P_{6}$ & $P_{7}$ & $P_{8}$ & $P_{9}$ & $P_{10}$ \\
\hline$A_{1}$ & 0.863 & 0.873 & 0.906 & 0.733 & 0.906 & 0.822 & 0.873 & 0.733 & 0.873 & 0.713 \\
\hline$A_{2}$ & 0.805 & 0.746 & 0.938 & 0.619 & 0.797 & 0.644 & 0.746 & 0.619 & 0.746 & 0.619 \\
\hline$A_{3}$ & 0.689 & 0.824 & 0.906 & 0.806 & 0.877 & 0.763 & 0.853 & 0.806 & 0.876 & 0.749 \\
\hline$A_{4}$ & 0.880 & 0.955 & 0.967 & 0.792 & 0.959 & 0.927 & 0.963 & 0.792 & 0.952 & 0.923 \\
\hline
\end{tabular}

Source: research calculation applying the Eq. 1, 2 and 3. 
Since it is more interesting to study the RES of groups of people, not individuals, some aggregation methods have to be applied. The authors selected the optimistic fuzzy aggregation norm $S$ defined in (Sokolov et al. 2019).

Let $x, y \in X$. The function $S: X \times X \rightarrow[0,1]$ is called an optimistic fuzzy aggregation norm if it justifies the conditions:

$(S 1) S(x, y) \in[0,1]$ (normalization)

(S2) $S(0,0)=0$ (border condition)

(S3) $S(x, y)=S(y, x)$ (commutativity)

(S4) $S(x, y)>\max \{x, y\}$ if $x \neq 0 \wedge y \neq 0$ (optimism).

The following optimistic fuzzy aggregation norm:

$$
S(x, y)=x+y-x y
$$

for $x, y \in[0,1]$ was selected to aggregate values in the paper.

Before the aggregation, since the different groups have different numbers of respondents, all $R_{3}$ values are divided by the number of respondents. Then the optimistic fuzzy aggregation norm (4) is applied, and levels of knowledge of different students' groups are calculated and presented in Table 4.

TABLE 4. The aggregated values of relation between research areas and groups of respondents

TABELA 4. Zagregowane wartości relacji pomiędzy obszarami badawczymi a grupami respondentów

\begin{tabular}{|c|c|c|c|c|c|c|c|c|}
\hline Respondents & $\begin{array}{c}\text { Urban } \\
\text { men }\end{array}$ & $\begin{array}{c}\text { Urban } \\
\text { women }\end{array}$ & $\begin{array}{c}\text { Rural } \\
\text { men }\end{array}$ & $\begin{array}{c}\text { Rural } \\
\text { women }\end{array}$ & Men & Women & $\begin{array}{c}\text { Urban } \\
\text { people }\end{array}$ & $\begin{array}{c}\text { Rural } \\
\text { people }\end{array}$ \\
\hline$A_{1}$ & 0.3876 & 0.3112 & 0.2847 & 0.3712 & 0.5740 & 0.5453 & 0.5576 & 0.5621 \\
\hline$A_{2}$ & 0.3657 & 0.2963 & 0.2652 & 0.3619 & 0.5497 & 0.5264 & 0.5298 & 0.5464 \\
\hline$A_{3}$ & 0.3797 & 0.3122 & 0.2792 & 0.3622 & 0.5685 & 0.5356 & 0.5478 & 0.5568 \\
\hline$A_{4}$ & 0.4205 & 0.3382 & 0.3141 & 0.3989 & 0.6121 & 0.5826 & 0.5980 & 0.5972 \\
\hline
\end{tabular}

Source: research calculation applying the Eq. 4.

Considering these results - levels of knowledge and understanding of the RES within different research areas, we can compare these respondents' groups. 


\section{Results}

While questioning people, the data gathered was vague and subjective because they were are asked about their opinion about some problems. When respondents estimated their opinions on the questions $\left(Q_{1}-Q_{8}\right)$, they found it challenging but assessing their feelings about the research areas $\left(A_{1}-A_{4}\right)$ would be more complicated. Of course, understanding and evaluating the truth levels of questions are easier because they affect only one aspect of the problem considered in the research areas. In this case, we need some method to connect questions with research areas, and the FLASR method is introduced to fulfill this purpose for each respondent separately. The next step of this method is aggregating the achieved respondents' results to some groups.

Based on the results of the FLASR methods presented in Table 1, the diagram of levels of respondents' group is prepared (Fig. 1).

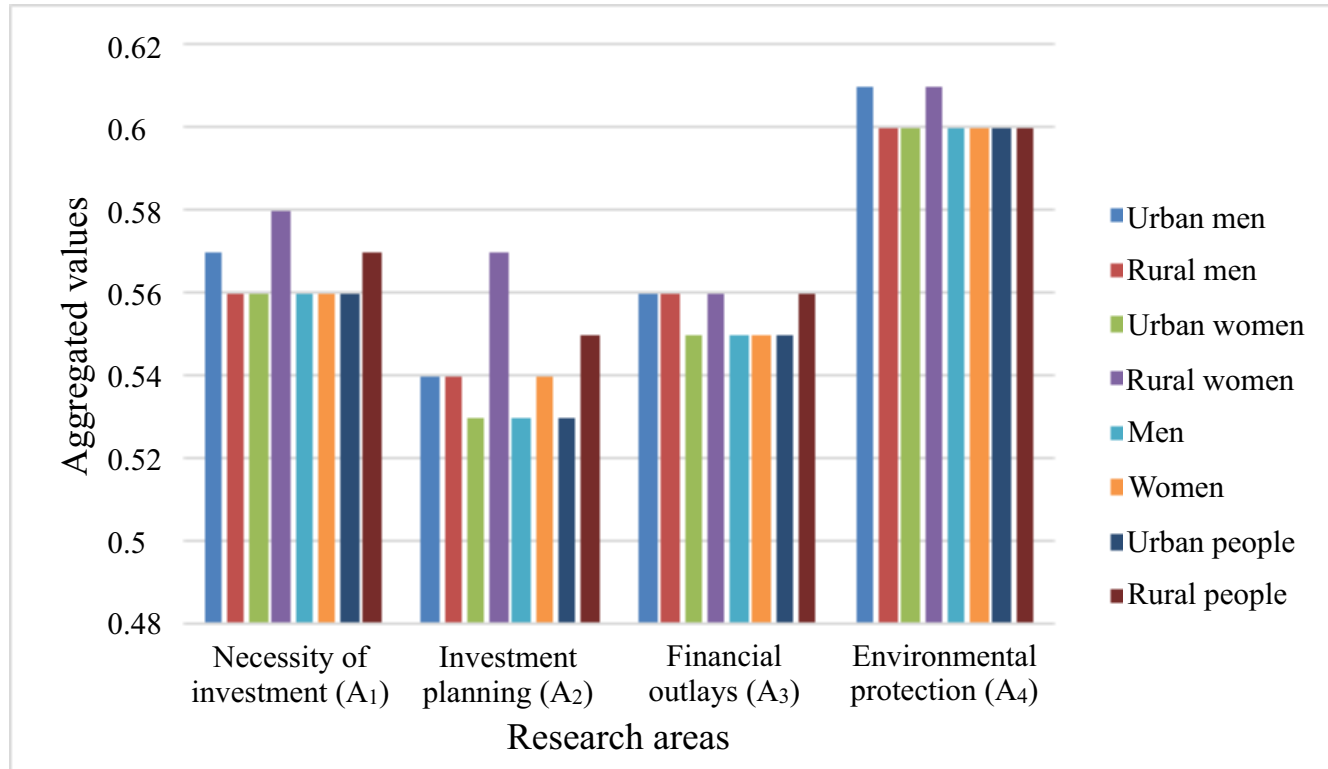

Fig. 1. Levels of students opinions of the discussed areas concerning gender and place of residence Source: own study based on Table 4

Rys. 1. Wartości opinii studentów na temat omawianych obszarów z podziałem na płeć i miejsce zamieszkania

The conducted analyses showed that in the area of "necessity of investment", research area $A_{1}$, (Fig. 1) that regardless of the place where the respondents live, young people expressed the view that investments in renewable energy are a must for the Polish economy because they result from the need to protect the environment. Rural residents and primarily women pointed out the importance of implementing ecological energy carriers. Moreover, it shows that urban men have 
a higher level of information than other respondents, and rural women, more often than rural men, gave more examples of sources for processing the discussed energy. For the analysis of this research area, questions $Q_{1}$ and $Q_{3}$ are the most important because they check the knowledge about RES and indicate the necessity of its implementation.

In turn, the analysis of the research area $A_{2}$, called investment planning, was mainly based on questions $Q_{2}$ and $Q_{4}$. We chose these questions because making a decision is a crucial issue (and a derivative of many factors, e.g., a preliminary analysis of financial needs or a renewable energy option for themselves). Choosing the best RES option affects drawing up the final business plan by selecting and matching the best solution for investors. Undoubtedly, the respondent must be convinced that such investments are essential for the country's energy sector (therefore, the importance of the interest in this area, question $Q_{2}$ ). With the share of equity, young people living in rural areas, especially women, were more likely to buy them. Urban people, if they already showed interest in purchasing such devices, were less likely to associate them with personal contributions and consider installing them with financial assistance from the state. They have more recent knowledge of national or EU subsidy sources among urban respondents in various aid programs for launching these installations. The FLASR method confirms that women want to invest in renewable energy more often and know more (compared to men) various forms of external support, which accelerate their purchase. They know Poland's funds for installing ecological energy equipment, namely the National Fund for Environmental Protection and Water Management and the Voivodship Funds for Environmental Protection and Water Management. Rural residents were more familiar with the support instrument 'My Electricity', while city dwellers were more interested in the 'Clean Air' program.

The following research area $A_{3}$ concerning investment outlays, and we understand that mainly questions $Q_{5}$ and $Q_{6}$ relate to this area. Academic students agree that these amounts are relatively high. Because when considering a given project, it is essential to analyze its costs, so estimating their financial resources to those offered by the state for the purchase of RES can help decide on a given technology. The group representing the inhabitants of rural areas (mostly women) was more firm about high prices for purchasing and installing renewable energy sources.

The next research area, $A_{4}$, is associated with questions $Q_{7}$ and $Q_{8}$. The critical question, $Q_{8}$, is that it is more challenging to invest in RES without external help, so question $Q_{7}$ was attached to this area's study. The increasing ecological awareness of the society and the promotion of green energy sources resulted in the separation of the 'environmental protection'. Young people are well aware that reducing the environmental burden of burning fossil fuels has become a necessity in the country. They know that the conditions for obtaining renewable energy support from the state are not sufficient, but on the other hand, they cannot block their development. Respondents' self-awareness about the beneficial impact of renewable energy sources for environmental protection is very high in all research groups, but the highest among urban and female residents. The rural respondents also signaled more often than those from cities that RES support from the state was sufficient in this respect (the responses of women and men in this group were similar to each other), which urban women did not confirm. Perhaps that is why they also more often than urban men sought external aid for RES. 
Summing up, we can notice that rural women, demonstrating willingness more often to invest in RES (engaging their own and even significant financial resources), have a more ecological approach to the discussed issues. They also had better insights (both from rural men and urban women) about the green energy technologies available on the market and about the possibilities to minimize the costs of buying them. Women from rural areas probably better understand the need to install renewable energy as a stimulus to launch new technological solutions on the market, thus reducing the impact of conventional coal energy on the environment.

Urban men are also a group that stands out from the rest. They notice the necessity of investments, which will ultimately translate into the protection of the environment in which they live. They knew more often (than the other groups included in the analysis: rural men and women) energy sources and equipment for their production and calculated their launch based on financial assistance from the state. When planning investments in RES in the future, they probably took into account, apart from the assumed improvement of their buildings' energy efficiency, that their actions would improve the city's quality of air. On the other hand, rural residents could associate renewable energy sources with reduced agricultural or processing sectors' expenditure.

The interviewees most likely concluded that they either assumed energy expenditure reduction or treated renewable energy as a future alternative to farming with a technologically advanced farm. This fact is highlighted in his study (Woźniak 2018), stressing that sustainable energy management in rural areas (based on RES) should, among other things, lead to the self-sufficiency of farms.

It should be remarked that young people notice the need to treat renewable energy as a sector with great use opportunities. The FLASR method presented in the paper confirmed the conclusions obtained based on statistical data analysis (Cichowska 2021) regarding the comparison between the considered groups of respondents in terms of questions related to the discussed issues.

The issue connected with renewable energy sources is a complex one, and we are going to continue its investigation. However, we think that the research procedure used (its stages, methodology, techniques used, question selection) is satisfactory at the moment because of the purposefulness of the problem posed and attempts to confirm it using the FLASR method. Due to the study's limited volume, we do not refer to all the issues raised in the survey. However, the vastness of renewable energy issues provides the basis for preparing a separate publication in this field.

The contemporary development of civilization and socio-economic life causes that tasks and problems formulated for science are more and more complex, exceeding the competencies of one discipline and, at the same time, the professional skills of a single scientist (Wierzchosławski 1996). The researchers' collaboration in various fields enables a new approach to inquiry and, as emphasized by (Gross and Stauffacher 2014), increases the ability to solve applied sciences and engineering problems, especially those related to the environment and sustainable development.

Comprehending the opinions of young people (students) on the role of renewable energy sources is very important because, as (Ruszkowski 2016) states, the real influence of society 
on political decisions in the field of energy development and environmental protection was primarily participation in parliamentary elections. In many environments, there are demands for greater empowerment of society in issues of high social sensitivity. Based on the research, the author formulated (together with the co-authors of the problem) a thesis that Poles already have a well-formed general energy awareness, including both preferences regarding the development of energy sources and opinions related to climate policy. At the same time, he emphasized that the problem of social trust in energy sources was analyzed in terms of their safety and prospects. In both dimensions, the highest confidence rates, over $80 \%$, were achieved by renewable energy sources, and, since 2015, these results have remained at the same very high level.

At the same time, a broad public opinion poll on renewable energy sources was also conducted in Poland by TNS Polska (a research agency dealing with public opinions), at the request of the Institute for Renewable Energy as part of the cooperation of a consortium of companies and national associations for the development of the 'National RES heat development plan'. This survey shows that Poles expect an increase in support for domestic renewable energy installations $(60 \%)$ and would most willingly use solar energy. Poles also notice the impact of renewable energy on increasing the clean natural environment standards in Poland (Gramwzielone.pl 2016). An essential element of the energy awareness of Poles is the perception of threats related to climate change. Nearly three-quarters of respondents estimate that environmental hazards associated with global warming and carbon dioxide emissions to the atmosphere are fundamental problems (Ruszkowski 2016).

Nevertheless, during the $3^{\text {rd }}$ Polish National Scientific Conference Energy security pillars and development perspective', which took place in 2018, scientists drew attention to the constant need to educate the public on renewable energy sources. They recognized that the lack of sufficient knowledge resulted in a low level of citizens' activity in this sector. They noticed a public interest in RES, support, and willingness to use such installations. However, the obstacle is the lack of information on legal regulations and the possibility of obtaining funding (these opinions coincide with those received by this paper's authors). At the same time, they argued that it was necessary to improve the environmental awareness of the society and the stability of energy supplies (especially in rural areas) and broaden the entrepreneurial attitudes of the inhabitants. They indicated (concerning the role of culture in the development of renewable energy sources) the model of citizens with high environmental awareness (implemented, inter alia, in Austria), voluntarily choosing RES installations in their households and actively participating in the energy market as prosumers (Kucharska 2018).

Residents of different countries think about the RES similarly. For example, most Americans would like to expand renewable sources to provide energy and do not support the increase in fossil fuel production (such as oil, gas, and nuclear power). Generally, Americans consider solar energy, which is influenced by financial matters and then environmental concerns (Pew Research Centre 2019). In turn, the UK researchers think that the British people's opinions about RES are a function of their feelings about the environment, neighborhood appearance, local community, economy, noise, and traffic. People who live nearby existing renewable energy constructions, males, and younger people are more likely to be optimistic about RES (Climate change 2012). 
Interesting observations can be found in the study by (Vand et al. 2019). The authors see the need to raise awareness of renewable energy sources among the inhabitants of China. They conclude that explaining green energy products' benefits is a fundamental tool to achieve a healthier environment. They also showed that over $70 \%$ of respondents thought about purchasing green energy products, but they lacked sufficient knowledge and awareness. Their results reveal that people's earnings and knowledge levels are substantial barriers to the purchase of green energy products. Moreover, (Qazi et al. 2019) also showed that the lack of social awareness of environmental problems is the main problem encountered by installing renewable energy technologies. To develop RES, they indicate the significance of the public knowledge and analyze social media tweets, which is a new way of researching social problems to produce recommendations for scientists and industry.

Young people are assigned a unique role in implementing ecological energy carriers by (Komendantova et al. 2018). The authors show that it is essential to understand young people's opinions on the implementation of RES since they constitute a substantial part of society and make decisions soon. Thus, their assistance and care to use green energy sources will be essential in RES development. Using a different methodology than in our study, they conclude that understanding influences the plan of using renewable energy. Therefore, policy-making procedures need to raise information campaigns targeted at young people to give them more information on renewable energy advantages.

The survey of university students examining knowledge about RES, including many aspects (like technical, economic, and policy), was conducted by (Assali et al. 2019). They showed a limited degree of self-awareness and knowledge of young people on this subject (the results are different from those obtained by the study's authors). (Zyadin 2015) states a shortage of research conducted to examine and learn how young people percept and what attitudes they present about RES, especially in developing countries. His study also showed that mainly women preferred renewable energy sources. He suggests that information campaigns using the mass media should be prepared to eliminate vagueness and doubts about the society's future energy sources.

The results' discussion confirms the validity of the research on RES among various social groups, including the youth population. Most authors emphasize the importance of the non-technical aspect when choosing green energy carriers. The construction of appropriate mechanisms stimulating the broader use of renewable energy sources requires recognizing the level of knowledge, attitudes of potential recipients, and their real needs. The opinion on the possibility of creating and modifying instruments supporting this type of initiative is also critical (Bieniecki et al. 2012). Their study revealed the state's need to promote these sources, access specialist knowledge, or ecological financing investment sources. The research groups highlighted some different opinions in this respect, therefore, the authors believe that scientific studies should emphasize market analyses conducted for a specific recipient of RES technology in the future. 


\section{Conclusions}

1. The respondents agree that sustainable energy development based on renewable energy sources is necessary for the Polish economy, resulting from reducing the harmful impact of burnt energy production on the environment. However, their implementation will only be possible if the state provides the society with appropriate economic instruments that will reduce their purchase costs.

2. Rural residents showed interest more often than city dwellers in the willingness to invest in green energy in the future. They probably notice that RES installations can cover the growing demand for energy in agriculture and make farms perceived as modern and environmentally friendly. This trend may also be dictated by rural residents' willingness to become independent of the professional energy sector. On the other hand, the attitude of young people from cities more distanced from the RES may result from investment limitations in the form of, e.g., lack of space for this type of installation, at the cost of purchasing land for such investment or a place to live (multi-family housing).

3. The analyses showed a varied knowledge of young people about the RES, which did not translate into declarations regarding future investments. Respondents from rural areas were (as already indicated) more interested. However, they spread information about them less frequently and were less aware of the state's help when purchasing them. Probably, therefore, their investment plans were mainly based on their capital. If they decided to invest in renewable energy sources, the more educated young people from cities in this area would primarily benefit from external funds.

4. Renewable energy sources require the constant promotion in the country and entities' involvement (local, provincial, national) encouraging people to implement ecological projects. Without public participation, it is impossible to implement the state-planned energy management concepts. Therefore, it is essential to recognize the expectations in this regard and to create incentives, especially economic ones, which, as the research has shown, constitute a serious barrier to investment.

5. When answers are subjective and uncertain, fuzzy logic may be very useful for analyzing collected data and drawing conclusions. With the application of data analysis based on the FLASR method, this survey clearly shows the relationship between respondents and questions and what is more interesting between research areas and respondents' groups. Thus, we can estimate levels of understanding areas distinguished in the RES issue among young people. 


\section{Appendix}

TABLE 1A. The values of relation $R_{2}$ between respondents and questions (urban men)

TABELA 1A. Wartości relacji $R_{2}$ między respondentami a pytaniami (mężczyźni z miasta)

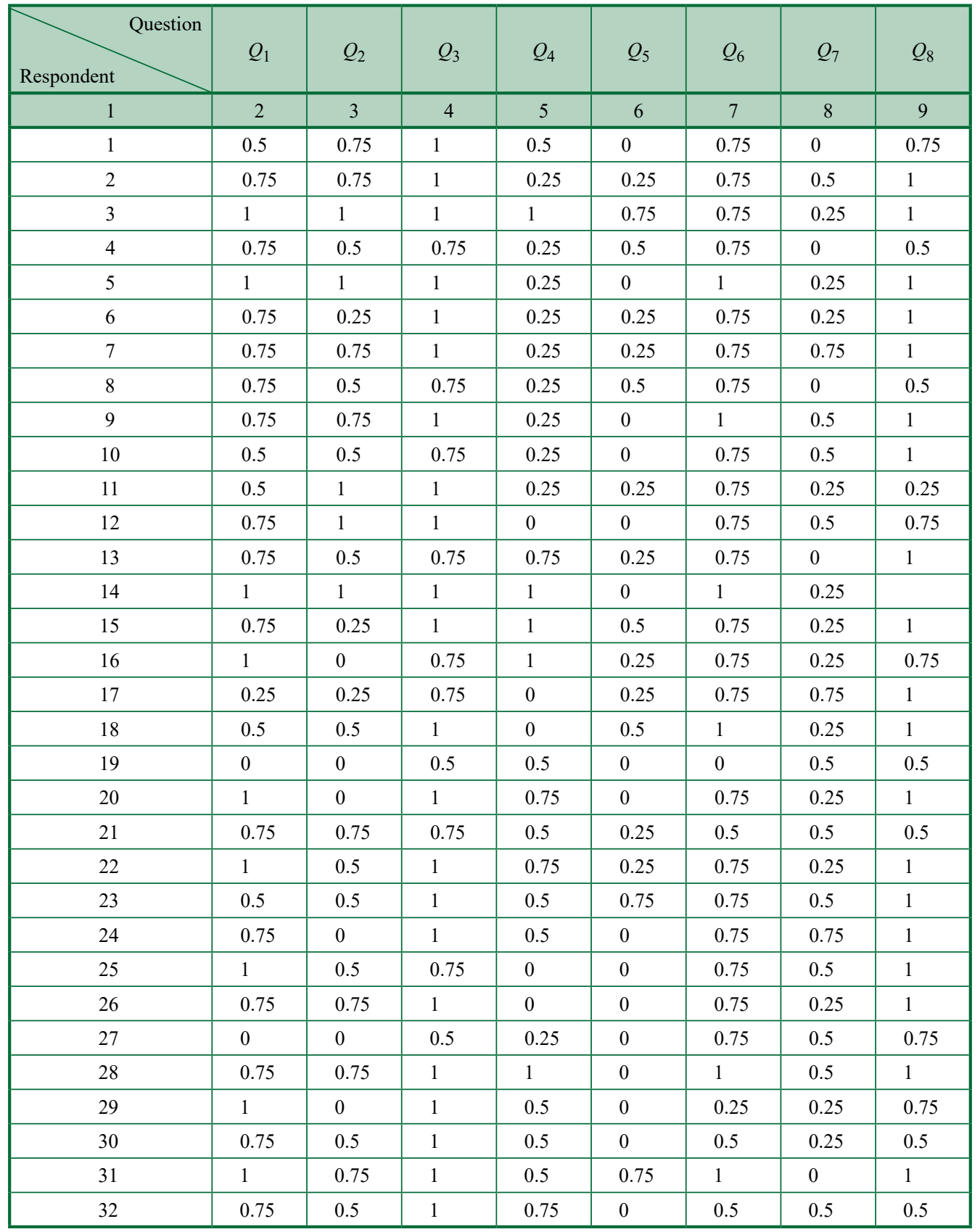

170 


\begin{tabular}{|c|c|c|c|c|c|c|c|c|}
\hline 1 & 2 & 3 & 4 & 5 & 6 & 7 & 8 & 9 \\
\hline 33 & 0.75 & 1 & 1 & 0.75 & 0.25 & 0.25 & 0 & 0.75 \\
\hline 34 & 0.75 & 0.75 & 0.75 & 0.75 & 0 & 0.5 & 0.25 & 1 \\
\hline 35 & 0.75 & 0.75 & 1 & 1 & 0 & 0.75 & 0.25 & 1 \\
\hline 36 & 0.75 & 0.75 & 1 & 0.75 & 0 & 0.75 & 0.25 & 1 \\
\hline 37 & 0.75 & 1 & 1 & 0.25 & 0.5 & 1 & 0.5 & 1 \\
\hline 38 & 0.75 & 0.75 & 0.75 & 0.25 & 0 & 0.75 & 0.5 & 0.75 \\
\hline 39 & 1 & 0.75 & 1 & 0.5 & 0 & 0.75 & 0 & 1 \\
\hline 40 & 1 & 1 & 1 & 1 & 0.25 & 1 & 0 & 1 \\
\hline 41 & 0.75 & 0.75 & 1 & 0.5 & 0 & 0.75 & 0.25 & 1 \\
\hline 42 & 0.75 & 0.75 & 0.75 & 0.5 & 0.75 & 1 & 0 & 0.5 \\
\hline 43 & 0.5 & 0.5 & 0.75 & 0 & 0.25 & 0.75 & 0.5 & 0.75 \\
\hline 44 & 0.5 & 0.25 & 1 & 0.5 & 0 & 0.75 & 0.25 & 1 \\
\hline 45 & 0.25 & 0.25 & 1 & 0.75 & 0 & 0.75 & 0.25 & 1 \\
\hline 46 & 0.5 & 0.5 & 1 & 0.75 & 0.25 & 1 & 0.75 & 1 \\
\hline 47 & 0.5 & 0.75 & 0.75 & 0 & 0 & 1 & 0 & 1 \\
\hline 48 & 0 & 0 & 0.5 & 0.5 & 0 & 1 & 0.5 & 0.25 \\
\hline 49 & 0.75 & 0.5 & 0.75 & 0 & 0 & 1 & 0.5 & 0.75 \\
\hline 50 & 1 & 0.5 & 1 & 0 & 0.25 & 1 & 0 & 1 \\
\hline 51 & 0.75 & 0.5 & 0.75 & 0.75 & 0 & 0.75 & 0 & 0.75 \\
\hline 52 & 0.75 & 1 & 0.75 & 0.5 & 0.5 & 0.75 & 0 & 1 \\
\hline 53 & 1 & 1 & 1 & 0.75 & 0.25 & 0.75 & 0.25 & 1 \\
\hline 54 & 0.75 & 0.75 & 1 & 0.5 & 0.75 & 0.75 & 0.25 & 1 \\
\hline 55 & 0.5 & 0.75 & 0 & 0 & 0.25 & 1 & 0 & 0.25 \\
\hline 56 & 0.75 & 0.75 & 1 & 0.75 & 0 & 0.75 & 0.25 & 1 \\
\hline 57 & 1 & 1 & 0.5 & 0.5 & 0.5 & 1 & 0.25 & 1 \\
\hline 58 & 1 & 0.75 & 1 & 0.75 & 0.5 & 0.75 & 0.75 & 0.5 \\
\hline 59 & 1 & 0.75 & 1 & 0.5 & 0.25 & 0.75 & 0 & 1 \\
\hline 60 & 1 & 0.75 & 1 & 0 & 0.25 & 1 & 0 & 1 \\
\hline 61 & 1 & 0.75 & 1 & 0.75 & 0.75 & 0.25 & 0 & 1 \\
\hline 62 & 1 & 1 & 0.75 & 0 & 0 & 1 & 0 & 0.75 \\
\hline 63 & 1 & 1 & 1 & 1 & 1 & 0 & 0 & 1 \\
\hline 64 & 1 & 0.75 & 1 & 0.5 & 0 & 0.75 & 0.5 & 1 \\
\hline 65 & 0.75 & 1 & 1 & 0 & 0 & 1 & 0 & 1 \\
\hline 66 & 1 & 0.75 & 0.75 & 0.25 & 0 & 0.5 & 0.75 & 0 \\
\hline 67 & 1 & 1 & 0.75 & 1 & 0.25 & 0.75 & 0 & 0.75 \\
\hline 68 & 1 & 0.75 & 1 & 0.75 & 0 & 1 & 0 & 1 \\
\hline 69 & 1 & 1 & 1 & 0 & 0 & 0.75 & 0 & 1 \\
\hline 70 & 0.5 & 0.5 & 1 & 1 & 0.25 & 0.75 & 0.25 & 0.25 \\
\hline 71 & 0.5 & 0.25 & 1 & 1 & 0.75 & 1 & 0 & 1 \\
\hline 72 & 0.5 & 0.5 & 1 & 0.75 & 0 & 0.75 & 0.5 & 1 \\
\hline
\end{tabular}




\begin{tabular}{|l|l|l|l|l|l|l|l|l|}
\hline 1 & 2 & 3 & 4 & \multicolumn{1}{|c|}{5} & \multicolumn{1}{|c|}{6} & \multicolumn{1}{|c|}{7} & \multicolumn{1}{|c|}{8} & 9 \\
\hline 73 & 1 & 0.5 & 0.75 & 0.25 & 0.5 & 0.75 & 0.5 & 0.75 \\
\hline 74 & 0.75 & 0 & 1 & 0.25 & 0.25 & 0.25 & 0 & 1 \\
\hline 75 & 0.75 & 0 & 1 & 0 & 0.25 & 0.75 & 0.5 & 0.75 \\
\hline 76 & 1 & 0.5 & 1 & 0.5 & 1 & 1 & 0.75 & 1 \\
\hline 77 & 1 & 0.75 & 1 & 0.75 & 0.5 & 1 & 0.25 & 1 \\
\hline 78 & 0.5 & 0.5 & 1 & 1 & 0 & 0.25 & 0.25 & 1 \\
\hline 79 & 0.75 & 0.75 & 1 & 1 & 0 & 0.25 & 0.5 & 1 \\
\hline 80 & 0.75 & 0.5 & 1 & 0.25 & 0 & 1 & 0.25 & 1 \\
\hline 81 & 0.75 & 0.5 & 0.75 & 0.5 & 0.25 & 1 & 0 & 0.75 \\
\hline 82 & 1 & 0.75 & 1 & 0.25 & 0.75 & 0.75 & 0.25 & 1 \\
\hline 83 & 0.75 & 0.75 & 1 & 1 & 0.5 & 1 & 0 & 1 \\
\hline 84 & 0.75 & 1 & 0.75 & 0.5 & 0.75 & 1 & 0.5 & 0.75 \\
\hline 85 & 0.5 & 0.5 & 0.75 & 0.75 & 0.75 & 0.75 & 0.25 & 0.5 \\
\hline 86 & 0.75 & 0.75 & 1 & 0.25 & 0 & 0.25 & 0.75 & 1 \\
\hline 87 & 0.5 & 1 & 1 & 0.75 & 0 & 0.75 & 0 & 1 \\
\hline 88 & 0.5 & 0.75 & 1 & 0 & 0.25 & 1 & 0 & 1 \\
\hline 89 & 0.5 & 0.5 & 1 & 0.25 & 0.75 & 0.5 & 0.25 & 0.75 \\
\hline
\end{tabular}


TABLE 1B. The values of relation $R_{2}$ between respondents and questions (rural men)

TABELA 1B. Wartości relacji $R_{2}$ między respondentami a pytaniami (mężczyźni ze wsi)

\begin{tabular}{|c|c|c|c|c|c|c|c|c|}
\hline Respondent & $Q_{1}$ & $Q_{2}$ & $Q_{3}$ & $Q_{4}$ & $Q_{5}$ & $Q_{6}$ & $Q_{7}$ & $Q_{8}$ \\
\hline 1 & 2 & 3 & 4 & 5 & 6 & 7 & 8 & 9 \\
\hline 1 & 1 & 1 & 0.75 & 0.25 & 0.75 & 1 & 0.5 & 1 \\
\hline 2 & 0.75 & 0.5 & 0.75 & 0.5 & 0 & 1 & 0.5 & 0.75 \\
\hline 3 & 0.75 & 0.75 & 1 & 0.75 & 0 & 0.75 & 0 & 1 \\
\hline 4 & 1 & 0.5 & 1 & 0.75 & 0.5 & 1 & 0 & 1 \\
\hline 5 & 0.25 & 0 & 0.75 & 0.5 & 1 & 0.5 & 0.75 & 0.5 \\
\hline 6 & 0.5 & 1 & 1 & 0.25 & 0 & 1 & 0.5 & 1 \\
\hline 7 & 0.25 & 0.5 & 1 & 0.25 & 0 & 0.75 & 0.5 & 1 \\
\hline 8 & 0.5 & 0.75 & 1 & 0.25 & 0.25 & 0.75 & 0.5 & 1 \\
\hline 9 & 0.75 & 0.75 & 1 & 0.5 & 0 & 0.75 & 0.5 & 1 \\
\hline 10 & 0.25 & 0.25 & 0.75 & 0.75 & 0.5 & 0.75 & 0.75 & 1 \\
\hline 11 & 0.75 & 1 & 0.75 & 0.25 & 0 & 0.75 & 0.5 & 1 \\
\hline 12 & 0.75 & 0.75 & 1 & 0 & 0.75 & 1 & 0.25 & 0.75 \\
\hline 13 & 1 & 0.5 & 1 & 0.5 & 0.75 & 0.75 & 0 & 1 \\
\hline 14 & 0.75 & 0.75 & 1 & 0.75 & 0.5 & 0.75 & 0.25 & 0.75 \\
\hline 15 & 0.75 & 0.75 & 1 & 0.75 & 0.5 & 0.75 & 0 & 0.75 \\
\hline 16 & 0.75 & 0.75 & 1 & 0 & 0 & 0.5 & 0.25 & 1 \\
\hline 17 & 0.5 & 0.5 & 1 & 1 & 0.5 & 0.5 & 0.25 & 1 \\
\hline 18 & 0.75 & 0.75 & 1 & 0.5 & 0 & 0.75 & 0.5 & 0.75 \\
\hline 19 & 1 & 1 & 1 & 1 & 0.5 & 1 & 0 & 1 \\
\hline 20 & 0.5 & 0.5 & 1 & 0.25 & 0 & 0.75 & 0.25 & 0.75 \\
\hline 21 & 0.5 & 0.5 & 0.5 & 0.25 & 0 & 0.75 & 0.5 & 0.5 \\
\hline 22 & 0.75 & 0.75 & 1 & 1 & 0.25 & 0.25 & 0.75 & 0.75 \\
\hline 23 & 0.75 & 0.75 & 1 & 0.5 & 0 & 0.75 & 1 & 1 \\
\hline 24 & 0.75 & 0 & 1 & 0.25 & 0 & 0.75 & 0.25 & 1 \\
\hline 25 & 1 & 0.5 & 1 & 0.25 & 0 & 1 & 0 & 0.75 \\
\hline 26 & 0.75 & 0.75 & 0 & 0 & 0 & 1 & 0 & 0 \\
\hline 27 & 0.5 & 0.5 & 0 & 0 & 0 & 1 & 0.5 & 0.25 \\
\hline 28 & 0.5 & 0.5 & 1 & 0.5 & 0.5 & 0.75 & 0.25 & 1 \\
\hline 29 & 1 & 0.75 & 1 & 1 & 0.75 & 0.75 & 0.25 & 0.75 \\
\hline 30 & 0.75 & 0.75 & 1 & 0.5 & 0.75 & 0.5 & 0.25 & 1 \\
\hline 31 & 0.75 & 0 & 1 & 0.75 & 0 & 1 & 0.25 & 0.75 \\
\hline 32 & 0.5 & 0.75 & 1 & 0.75 & 0.75 & 0.75 & 0 & 0.75 \\
\hline 33 & 1 & 0.75 & 1 & 0.75 & 1 & 0.75 & 0 & 1 \\
\hline 34 & 0.75 & 0.75 & 1 & 1 & 0 & 0.75 & 0.75 & 0.5 \\
\hline
\end{tabular}




\begin{tabular}{|l|l|l|l|l|l|l|l|l|}
\hline 1 & 2 & 3 & 4 & 5 & 6 & 7 & 8 & 9 \\
\hline 35 & 0.25 & 0.25 & 1 & 1 & 0.25 & 0.75 & 0.75 & 1 \\
\hline 36 & 0.75 & 0.75 & 0.75 & 0 & 0 & 0.5 & 0.5 & 0.5 \\
\hline 37 & 1 & 0.75 & 1 & 0.75 & 0 & 0.5 & 0 & 0.75 \\
\hline 38 & 1 & 0.5 & 1 & 1 & 0.25 & 1 & 0 & 1 \\
\hline 39 & 0.75 & 0.75 & 0.75 & 0.75 & 0 & 0.5 & 0.5 & 0 \\
\hline
\end{tabular}


TABLE 1C. The values of relation $R_{2}$ between respondents and questions (urban women)

TABELA 1C. Wartości relacji $R_{2}$ między respondentami a pytaniami (kobiety z miasta)

\begin{tabular}{|c|c|c|c|c|c|c|c|c|}
\hline Respondent & $Q_{1}$ & $Q_{2}$ & $Q_{3}$ & $Q_{4}$ & $Q_{5}$ & $Q_{6}$ & $Q_{7}$ & $Q_{8}$ \\
\hline 1 & 2 & 3 & 4 & 5 & 6 & 7 & 8 & 9 \\
\hline 1 & 0.5 & 0.75 & 1 & 0.75 & 0 & 0.25 & 1 & 1 \\
\hline 2 & 0.25 & 0.25 & 1 & 0.25 & 0.75 & 0.5 & 0.5 & 0.75 \\
\hline 3 & 0.75 & 0.75 & 1 & 0.5 & 0 & 0.75 & 0.5 & 1 \\
\hline 4 & 0 & 0 & 0.75 & 0 & 0 & 0.5 & 0.5 & 0.5 \\
\hline 5 & 1 & 0.5 & 0.75 & 0.75 & 0.25 & 0.75 & 0.5 & 0.5 \\
\hline 6 & 1 & 0.5 & 0.25 & 0 & 0.5 & 0.75 & 0 & 1 \\
\hline 7 & 0.75 & 0.75 & 1 & 0.5 & 0 & 1 & 0.25 & 1 \\
\hline 8 & 0.75 & 0.75 & 0.75 & 0.75 & 0 & 0.75 & 0.5 & 1 \\
\hline 9 & 1 & 0.5 & 1 & 0.5 & 0.75 & 0.75 & 0.25 & 1 \\
\hline 10 & 0.25 & 0.25 & 1 & 0.5 & 0 & 0.75 & 0 & 1 \\
\hline 11 & 1 & 0.75 & 0.75 & 0 & 0.25 & 0.75 & 0.25 & 0.75 \\
\hline 12 & 0.75 & 0 & 1 & 0.5 & 1 & 0.75 & 0 & 1 \\
\hline 13 & 0.75 & 0.5 & 1 & 0.25 & 0 & 0.75 & 0.25 & 0.75 \\
\hline 14 & 0.75 & 0.5 & 1 & 0.25 & 0 & 0.75 & 0 & 1 \\
\hline 15 & 0.5 & 0.5 & 1 & 0.5 & 0.75 & 0.75 & 0.5 & 0.5 \\
\hline 16 & 0.75 & 0.25 & 0.75 & 0.25 & 0.25 & 0.75 & 0.25 & 1 \\
\hline 17 & 0.75 & 0.5 & 1 & 0 & 0.5 & 1 & 0 & 1 \\
\hline 18 & 0.5 & 0.5 & 1 & 0.25 & 0.25 & 0.75 & 0.25 & 1 \\
\hline 19 & 0.75 & 0.75 & 1 & 1 & 0.75 & 0.75 & 0.25 & 1 \\
\hline 20 & 0.5 & 0.5 & 1 & 0.75 & 0.25 & 0.75 & 0.25 & 1 \\
\hline 21 & 0.75 & 0.75 & 1 & 0.75 & 0.25 & 1 & 0.25 & 0.75 \\
\hline 22 & 0.75 & 0.5 & 1 & 0.25 & 0.75 & 0.75 & 0.5 & 0.75 \\
\hline 23 & 0.5 & 0.5 & 1 & 0.75 & 0.25 & 0.75 & 0.25 & 1 \\
\hline 24 & 0.75 & 0.5 & 1 & 0.75 & 0 & 0.75 & 0 & 0.75 \\
\hline 25 & 0.25 & 0.25 & 1 & 1 & 0.25 & 0.25 & 0.75 & 1 \\
\hline 26 & 0.75 & 0 & 1 & 0.75 & 0.5 & 0.75 & 0.25 & 0.75 \\
\hline 27 & 0.75 & 0.75 & 1 & 0.25 & 0 & 0.75 & 0.25 & 1 \\
\hline 28 & 0.5 & 0.5 & 1 & 0.5 & 0.25 & 0.75 & 0.25 & 1 \\
\hline 29 & 0.25 & 0.25 & 0.75 & 0.25 & 0.75 & 0.75 & 0.25 & 0.75 \\
\hline 30 & 0 & 0 & 0.75 & 0.25 & 0.75 & 0.75 & 0.25 & 1 \\
\hline 31 & 0.5 & 0.5 & 0.75 & 0.5 & 0.5 & 0.75 & 0.25 & 0.5 \\
\hline 32 & 0.75 & 0.75 & 0.75 & 0.25 & 0.25 & 0.75 & 0 & 0.75 \\
\hline 33 & 0.75 & 0.75 & 1 & 0.75 & 0.75 & 0.25 & 0.25 & 1 \\
\hline 34 & 0.5 & 0 & 1 & 1 & 0.25 & 0.75 & 0.25 & 1 \\
\hline
\end{tabular}




\begin{tabular}{|c|c|c|c|c|c|c|c|c|}
\hline 1 & 2 & 3 & 4 & 5 & 6 & 7 & 8 & 9 \\
\hline 35 & 0.75 & 0.5 & 1 & 0.75 & 0.25 & 1 & 0.25 & 1 \\
\hline 36 & 1 & 0.75 & 1 & 1 & 0 & 1 & 0.5 & 1 \\
\hline 37 & 0.75 & 0.75 & 1 & 0.25 & 0 & 1 & 0 & 1 \\
\hline 38 & 0.75 & 1 & 1 & 1 & 0.5 & 1 & 0.5 & 1 \\
\hline 39 & 0.75 & 0.75 & 0.75 & 0 & 0 & 0.75 & 0.5 & 0.75 \\
\hline 40 & 0.75 & 0.75 & 1 & 1 & 0.25 & 0.75 & 0.25 & 0.75 \\
\hline 41 & 0.75 & 0.75 & 1 & 0.75 & 0.25 & 0.5 & 0.5 & 1 \\
\hline 42 & 1 & 0.5 & 1 & 0.5 & 0.25 & 0.75 & 0.5 & 1 \\
\hline 43 & 1 & 0 & 1 & 0 & 0 & 0.75 & 0.5 & 1 \\
\hline 44 & 1 & 0.75 & 1 & 0.25 & 0 & 0.75 & 0.25 & 1 \\
\hline 45 & 0.5 & 0.25 & 1 & 0.25 & 0 & 0.5 & 0.25 & 0.75 \\
\hline 46 & 0.75 & 0.75 & 1 & 0.25 & 0.25 & 0.75 & 0.25 & 1 \\
\hline 47 & 0.5 & 0.75 & 1 & 0.25 & 0.25 & 0.75 & 0.25 & 0.75 \\
\hline 48 & 1 & 0.75 & 1 & 0.75 & 0.5 & 1 & 0 & 1 \\
\hline 49 & 0.75 & 0.5 & 1 & 0.75 & 0.25 & 0.75 & 0.5 & 1 \\
\hline 50 & 1 & 1 & 1 & 0.5 & 0.75 & 0.25 & 0.25 & 1 \\
\hline 51 & 0.75 & 1 & 1 & 0.25 & 0.75 & 0.75 & 0.75 & 1 \\
\hline 52 & 0.5 & 0.75 & 1 & 0.75 & 0.25 & 0.75 & 0.25 & 0.75 \\
\hline 53 & 1 & 0.75 & 1 & 0.25 & 0.5 & 1 & 0.25 & 1 \\
\hline 54 & 0.5 & 0.75 & 0.75 & 0.75 & 0.25 & 0.5 & 0.75 & 1 \\
\hline 55 & 0.5 & 0.5 & 1 & 0.75 & 0.75 & 0.75 & 0.25 & 0.5 \\
\hline 56 & 1 & 0.75 & 1 & 1 & 0.25 & 0.75 & 0 & 1 \\
\hline 57 & 0.25 & 0 & 0.75 & 0 & 0 & 1 & 0 & 1 \\
\hline 58 & 1 & 1 & 1 & 1 & 0.25 & 0.75 & 0.25 & 0.75 \\
\hline 59 & 1 & 1 & 1 & 0.75 & 0 & 1 & 0 & 1 \\
\hline 60 & 1 & 1 & 1 & 0.75 & 0 & 0.25 & 0 & 1 \\
\hline 61 & 0.75 & 0.25 & 0.75 & 0.25 & 0.5 & 1 & 0.25 & 1 \\
\hline 62 & 0.5 & 0 & 0.75 & 0.5 & 0.5 & 0.75 & 0.25 & 1 \\
\hline
\end{tabular}


TABLE 1D. The values of relation $R_{2}$ between respondents and questions (rural women)

TABELA 1D. Wartości relacji $R_{2}$ między respondentami a pytaniami (kobiety ze wsi)

\begin{tabular}{|c|c|c|c|c|c|c|c|c|}
\hline Respondent & $Q_{1}$ & $Q_{2}$ & $Q_{3}$ & $Q_{4}$ & $Q_{5}$ & $Q_{6}$ & $Q_{7}$ & $Q_{8}$ \\
\hline 1 & 2 & 3 & 4 & 5 & 6 & 7 & 8 & 9 \\
\hline 1 & 0.5 & 0.5 & 1 & 1 & 0.25 & 0.75 & 0.75 & 1 \\
\hline 2 & 1 & 1 & 1 & 1 & 1 & 0.75 & 0.25 & 1 \\
\hline 3 & 0.5 & 0.5 & 0.75 & 0.25 & 0.25 & 1 & 0.25 & 0 \\
\hline 4 & 0.25 & 0 & 0.75 & 0.75 & 0 & 0.75 & 0.25 & 1 \\
\hline 5 & 0 & 0 & 0.75 & 1 & 0 & 0.75 & 0.25 & 0.75 \\
\hline 6 & 0.25 & 0.25 & 1 & 0.75 & 0.25 & 1 & 0.25 & 1 \\
\hline 7 & 0.75 & 0.5 & 0.75 & 0.75 & 0.5 & 1 & 0.5 & 0.75 \\
\hline 8 & 1 & 0.75 & 1 & 1 & 1 & 0.75 & 0.25 & 1 \\
\hline 9 & 1 & 0.5 & 1 & 0.75 & 1 & 0.75 & 0.75 & 1 \\
\hline 10 & 0.75 & 0.5 & 1 & 0.25 & 0 & 0.75 & 0 & 1 \\
\hline 11 & 1 & 1 & 1 & 0.5 & 0.25 & 0.5 & 0.25 & 1 \\
\hline 12 & 0.75 & 0.75 & 1 & 1 & 0.5 & 1 & 0.25 & 1 \\
\hline 13 & 0.75 & 0.75 & 0.75 & 0.75 & 0.5 & 1 & 0.5 & 0.5 \\
\hline 14 & 0.75 & 0.75 & 1 & 0.25 & 0 & 0.75 & 0.25 & 1 \\
\hline 15 & 0.75 & 0.5 & 1 & 1 & 0.25 & 0.25 & 0.75 & 1 \\
\hline 16 & 0.5 & 0.75 & 1 & 0.25 & 0 & 0.75 & 0.75 & 0.75 \\
\hline 17 & 1 & 0 & 1 & 0.75 & 0.5 & 0.25 & 1 & 0.75 \\
\hline 18 & 0.5 & 0 & 1 & 0.5 & 0.25 & 1 & 0 & 0.75 \\
\hline 19 & 0.75 & 0.75 & 1 & 0 & 0.25 & 0.75 & 0.25 & 1 \\
\hline 20 & 0.75 & 0.5 & 1 & 1 & 0 & 0.75 & 0.75 & 1 \\
\hline 21 & 1 & 1 & 1 & 0.75 & 0.25 & 1 & 0.25 & 1 \\
\hline 22 & 0.75 & 1 & 1 & 0.75 & 0.75 & 0.75 & 0.25 & 1 \\
\hline 23 & 0.75 & 0.5 & 1 & 0 & 0 & 1 & 0 & 0 \\
\hline 24 & 0.75 & 0.75 & 1 & 0.75 & 0.25 & 0.75 & 0.5 & 0.75 \\
\hline 25 & 1 & 0.75 & 1 & 0.25 & 0 & 0.75 & 0.25 & 0.75 \\
\hline 26 & 0.75 & 0.5 & 1 & 1 & 0 & 1 & 0.25 & 1 \\
\hline 27 & 1 & 1 & 1 & 1 & 0.75 & 1 & 0 & 1 \\
\hline 28 & 1 & 1 & 1 & 1 & 0.5 & 0.75 & 0.25 & 0.75 \\
\hline 29 & 0.75 & 0.25 & 0.75 & 1 & 0 & 0.5 & 0.5 & 0.75 \\
\hline 30 & 0.75 & 1 & 1 & 1 & 0 & 0.75 & 0 & 1 \\
\hline 31 & 1 & 0.5 & 1 & 1 & 0 & 0.75 & 0.25 & 1 \\
\hline 32 & 0.75 & 0.5 & 1 & 0.75 & 0.25 & 0.75 & 0.25 & 1 \\
\hline 33 & 1 & 0 & 1 & 1 & 0 & 0.75 & 0 & 1 \\
\hline 34 & 0.75 & 0.75 & 1 & 0 & 0 & 0.5 & 0 & 1 \\
\hline
\end{tabular}




\begin{tabular}{|l|l|l|l|l|l|l|l|l|}
\hline 1 & 2 & 3 & 4 & 5 & 6 & 7 & 8 & 9 \\
\hline 35 & 0.75 & 0.75 & 1 & 0 & 0 & 0.5 & 0.25 & 1 \\
\hline 36 & 0.75 & 0.5 & 1 & 0.5 & 0.25 & 0.5 & 0.75 & 1 \\
\hline 37 & 0.75 & 0.75 & 1 & 0.75 & 0 & 0.75 & 0.25 & 1 \\
\hline 38 & 0.75 & 0.75 & 1 & 0.25 & 0.5 & 1 & 0.5 & 1 \\
\hline 39 & 0.75 & 0.75 & 1 & 0.25 & 0.25 & 1 & 0.5 & 1 \\
\hline 40 & 0.75 & 0.5 & 0.75 & 0.25 & 0.25 & 1 & 0.25 & 0.75 \\
\hline 41 & 0.75 & 1 & 1 & 0.75 & 0.75 & 1 & 0.25 & 0.75 \\
\hline 42 & 0.75 & 0.75 & 1 & 0.5 & 0.75 & 0.25 & 0 & 1 \\
\hline 43 & 0.5 & 0.5 & 1 & 0.5 & 0.25 & 0.75 & 0.5 & 0.75 \\
\hline 44 & 0.25 & 0.5 & 0.75 & 0.5 & 0 & 0.75 & 0.5 & 0.25 \\
\hline 45 & 0.75 & 0.75 & 1 & 0.25 & 0.75 & 0.5 & 0.5 & 1 \\
\hline 46 & 0.5 & 0.5 & 1 & 0.5 & 0.25 & 1 & 0.5 & 1 \\
\hline
\end{tabular}




\section{References}

AsH, E.A. 2001. Economic instruments and the prospects for non-fossil fuel energy. Interdisciplinary Science Reviews (26)4, pp. 258-264, DOI: 10.1179/ isr.2001.26.4.258.

Assali et al. 2019 - Assali, A., Khatib, T. and NajJar, A. 2019. Renewable energy awareness among future generation of Palestine. Renewable Energy 136, pp. 254-263, DOI: 10.1016/j.renene.2019.01.007.

BABBIE, E. 2001. The practice of social research. Wadsworth/Thomson Learning.

BienieCKi et al. 2012 - BienieCKi, M., MAJER, M., MARTYKA, J. and NowAK, K. 2012. Non-technical conditions for the use of renewable energy sources in construction. Social Research Report. Research reports mining and environment 4, pp. 18-44.

Chandran, S. and Kandaswamy, G. 2016. A fuzzy approach to transport optimization problem. Optim. Eng. 17, pp. 965-980, DOI: 10.1007/s11081-012-9202-6.

CichowsKa, J.B. 2021. Prospects for the development of renewable energy sources in the opinion of urban and rural residents (Perspektywy rozwoju odnawialnych źródet energii w opinii mieszkańców miast oraz wsi). Zasoby infrastrukturalne i środowiskowe w gospodarce o obiegu zamkniętym/Infrastructure and environmental resources in circular economy, Kraków: Wyd. IGSMiE PAN (in print) (in Polish).

Climate change 2012. How the UK public feels about renewable energy. [Online] https://www.climatexchange.org.uk/media/1734/shaping_our_energy_future_-_how_the_public_feels_about_renewable_ energy.pdf [Accessed: 2020-08-12].

FelLS, I. 1996. New methods of power generation. Interdisciplinary Science Reviews 21(3), pp. 192-194, DOI: $10.1179 /$ isr.1996.21.3.192.

FELLS, I. 2000. Can the energy market protect the environment? Interdisciplinary Science Reviews 25(1), pp. 29-33, DOI: 10.1179 / isr.2000.25.1.29.

Geleta, D. and Manshahia, M. 2017. Optimization of Renewable Energy Systems: A Review. International Journal of Scientific Research in Science and Technology 3, pp. 769-795. [Online] https://www. researchgate.net/publication/321917914 [Accessed: 2021-02-19].

Gramwzielone.pl, 2016. What do Poles think about RES? TNS Polska survey (Co Polacy sadza o OZE? Badanie TNS Polska). [Online] https://www.gramwzielone.pl/trendy/20081/co-polacy-sadza-o-ozebadanie-tns-polska [Accessed: 2021-02-10] (in Polish).

Gross, M. and Stauffacher, M. 2014. Transdisciplinary Environmental Science: Problem-oriented Projects and Strategic Research Programs. Interdisciplinary Science Reviews 39(4), pp. 299-306, DOI: 10 $.1179 / 0308018814 Z .00000000093$.

Houghton, J. 2001. The science of global warming. Interdisciplinary Science Reviews 26(4), pp. 247-257, DOI: 10.1179 / isr.2001.26.4.247.

JANeIRo, L. and ReSCH, G. 2017. RES target achievement forecast for Poland, Final Report (Prognoza realizacji celu OZE dla Polski, Raport końcowy). Ecofys, Numer projektu: EPODE17004, Technische Universtat Wien, pp. 5-35. [Online] https://www.teraz-srodowisko.pl/media/pdf/aktualnosci /3273-progoza-realizacji-celu-oze-2020-dla-polski.pdf [Accessed: 2021-02-25] (in Polish).

Komendantova, N., Yazdanpanah, M. and Shafiei, R. 2018. Studying young people' views on deployment of renewable energy sources in Iran through the lenses of Social Cognitive Theory. AIMS Energy 6(2), pp. 216-229, DOI: 10.3934/energy.2018.2.216.

KuCharsKa, A. 2018. Experts: Public education needed vs. RES (Eksperci: Potrzebna edukacja spoteczeństwa ws. OZE). Energetyka 24. [Online] https://www.energetyka24.com/eksperci-potrzebna-edukacja-spoleczenstwa-ws-oze [Accessed: 2021-02-10] (in Polish).

LiKERT, R.A. 1932. A technique for the measurement of attitudes. Archives of Psychology 140, pp. 1-55.

ManowsKa, A. 2019. Renewable energy sources in the national energy mix (Odnawialne źródta energii w krajowym miksie energetycznym). Zeszyty Naukowe Instytutu Gospodarki Surowcami Mineralnymi 
i Energia Polskiej Akademii Nauk 109, pp. 111-122, DOI: 10.24425/znigsme.2019.130162 (in Polish).

Owusu, A.P. AND Asumadu-Sarkodie, S. 2016. A review of renewable energy sources, sustainability issues and climate change mitigation. Cogent Engineering 3(1), DOI: 10.1080/ 23311916.2016. 1167990.

PAwLAK, S. 2019. Renewable energy guide for the advisor (Poradnik OZE dla doradcy). Poznań: Centrum Doradztwa Rolniczego w Brwinowie Oddział w Poznaniu, pp. 6-27 (in Polish).

PerZyŃsKi, M. 2020. The success of the EU climate policy. The RES target for 2020 has been achieved (Sukces unijnej polityki klimatycznej. Udało się osiagnać cel OZE na 2020 rok). Biznes Alert. [Online] https://biznesalert.pl/sukces-unijnej-polityki-klimatycznej-udalo-sie-osiagnac-cel-oze-na-2020-rok/ [Accessed: 2021-02-26] (in Polish).

Pew Research Centre. Science \& Society 2016. Public opinion on renewables and other energy sources, [Online] https://www.pewresearch.org/ science/2016/10/04/public-opinion-on-renewables-and-otherenergy-sources/ [Accessed: 2020-08-12].

RuszKowsKi, P. 2016. Energy and public opinion (Energetyka a opinia publiczna). [In:] Gwiazda, M. and Ruszkowski, P. Poles on energy sources, energy policy, and the state of the environment (Polacy oźródtach energii, polityce energetycznej i stanie środowiska). Opinie i Diagnozy 34, Warszawa: Centrum Badania Opinii Społecznej, pp. 5-7 (in Polish).

Rutкowski, L. 2009. Methods and techniques of artificial intelligence (Metody i techniki sztucznej inteligencji). Warszawa: Wyd. Nauk. PWN (in Polish)

Santos et al. 2017 - Santos, S.F., Fitiwi, D.Z., Shafie-Khah M., Bizuayehu, A.W. and Catalão, J.P.S. 2017. Introduction to Renewable Energy Systems. Optimization in Renewable Energy Systems, Istanbul: Yildiz Technical University, pp. 1-26, DOI:10.1016/B978-0-08-101041-9.00001-6.

SidHU et al. 2016 - SidHU, S.K., Kumar, A. and KaUR, A. 2016. A note on 'A fuzzy approach to transport optimization problem'. Optim. Eng. 17, pp. 987-992, DOI: 10.1007/s11081-015-9279-9.

Sokolov et al. 2019 - Sokolov, O., Osińska, W., Mreza, A. and Duch, W. 2019. Modeling of Scientific Publications Disciplinary Collocation Based on Optimistic Fuzzy Aggregation Norms, Advances in Intelligent Systems and Computing. [In:] Proceedings of $39^{\text {th }}$ International Conference on Information Systems Architecture and Technology ISAT 2018 Part II (Świątek, J., Borzemski, L. and Wilimowska, Z.), Information Systems Architecture and Technology 853, pp.145-156.

Soloma, L. 2002. Methods and techniques of sociological research. Selected issues (Metody i techniki badań socjologicznych. Wybrane zagadnienia). Olsztyn: Wydawnictwo Uniwersytetu Warmińsko-Mazurskiego, pp. 63-67 (in Polish).

SowA, S. 2018. Renewable energy sources as a factor contributing to the improvement of energy efficiency (Odnawialne źródła energii jako czynnik wptywajacy na poprawę efektywności energetycznej). Zeszyty Naukowe Instytutu Gospodarki Surowcami Mineralnymi i Energia Polskiej Akademii Nauk 105, pp. 187-196, DOI: 10.24425/124381 (in Polish).

Szczerbowski, R. and Ceran B. 2017. Polish energy policy in the context of the challenges of the twenty-first century (Polityka energetyczna Polski w aspekcie wyzwań XXI wieku). Polityka EnergetycznaEnergy Policy Journal 20(3), pp. 17-28 (in Polish).

Qazi et al. 2019 - Qazi, A., Hussain, F., Rahim, N.A., Hardaker G., Alghazzawi, D., Shaban, K. and HarunA, K. 2019. Towards Sustainable Energy: A Systematic Review of Renewable Energy Sources. Technologies and Public Opinions. [In:] IEEE Access 7, pp. 63837-63851, DOI: 10.1109/ACCESS.2019.2906402.

VAND et al. 2019 - VAnd, B., Hast, A., Bozorg, S., Li, Z., SAnna, S. and Deng, S. 2019. Consumers' Attitudes to Support Green Energy: A Case Study in Shanghai. Energies 12, DOI: 10.3390/ en12122379. 
WiERzCHOSŁAWSKI, S. 1996. Multidisciplinarity and interdisciplinarity of statistical research on the social phenomenon (Wielodyscyplinarność $i$ interdyscyplinarność statystycznych badań zjawisko spotecznych). Ruch Prawniczy, Ekonomiczny i Socjologiczny LVIII(1), pp. 85-101 (in Polish).

WoźNIAK, M. 2018. Sustainable energy management in rural areas in Poland (Zrównoważona gospodarka energetyczna na obszarach wiejskich w Polsce). Polityka Energetyczna - Energy Policy Journal 21(1), pp. 69-84 (in Polish).

ZADEH, L.A. 1965. Fuzzy sets. Information and Control 8(3), pp. 338-353.

ZYADIN, A. 2015. Prospects for renewable energy education (REE) in elevating youth energy and environmental awareness in Jordan. Dissertationes Forestales 207(39), DOI: 10.14214/df.207.

\section{Znaczenie sektora energetyki odnawialnej w opinii młodzieży wiejskiej i miejskiej}

\section{Streszczenie}

Obserwowany w ostatnich latach wzrost zainteresowania zieloną energią stał się podstawą do przeprowadzenia pilotażowych badań dotyczących jej roli w produkcji energii elektrycznej w Polsce. Metoda sondażu diagnostycznego pozwoliła poznać opinie młodych ludzi na temat odnawialnych źródeł energii w kontekście czterech zidentyfikowanych obszarów badawczych (konieczność OZE, planowanie jej instalacji, koszty, wpływ na środowisko). Do opracowania i interpretacji wyników badań ankietowych zastosowano metodę opartą na logice rozmytej (relacjach rozmytych i optymistycznych rozmytych normach agregacji), aby lepiej zrozumieć wiedzę wybranej społeczności na temat ważności (lub nie) OZE w krajowym systemie energetycznym. $Z$ badania wynika, że choć nie ma znaczącej różnicy między grupami respondentów we wszystkich obszarach badawczych, to można zauważyć, że kobiety mieszkające na wsi są bardziej zainteresowane wykorzystaniem ekologicznych technologii. Posiadają one wysoką samoświadomość w zakresie ich dobroczynnego wpływu na środowisko. Respondenci wiejscy, w porównaniu z tymi z miasta, są skłonni (pomimo wysokich kosztów urządzeń) angażować własny kapitał na zakup zielonych nośników energii, co jest podyktowane ich niższą wiedzą na temat form wsparcia zewnętrznego. W zależności od pochodzenia wybierano różne rządowe programy pomocowe na OZE. Osoby z miasta decydowały się głównie na te, które w miejscu ich zamieszkania poprawią komfort jakości powietrza atmosferycznego. Z kolei mieszkańcy wsi skupiali swoją uwagę na wykorzystaniu instrumentów pomocowych, dających w przyszłości obniżenie kosztów energii w prowadzonych gospodarstwach rolnych. Wszyscy respondenci są zgodni, że inwestycje w czystą energię przełożą się na szeroko pojętą ochronę środowiska, przynosząc wszystkim obopólne korzyści.

SŁoWA KLUCZOWE: odnawialne źródła energii, czysta energia, studenci, logika rozmyta, optymistyczne rozmyte normy agregacji 
